\title{
AN INTERNATIONAL PROGRAM IN RAILROAD ENGINEERING
}

\author{
Pasi T. Lautala and William J. Sproule \\ Department of Civil and Environmental Engineering \\ Michigan Technological University
}

\section{Introduction}

The railroad industry has identified a need for engineers as many will be retiring over the next few years and freight traffic is projected to increase. The challenge for railroads is finding engineers when careers in railroad engineering have been forgotten on most university campuses. Michigan Tech University saw a unique opportunity for a six-credit summer program that includes an introductory course in railroad engineering, a course in a foreign language and culture, and a study abroad component. The summer program has been a great success and has drawn students from several engineering disciplines and universities. It has been offered for four summers and the rail industry has responded with enthusiastic support by providing guest speakers, scholarships, and internships, and several of the program participants are now working in the industry. This paper describes the five-week summer program in which students spend one week on campus, one-half week in Chicago, and three and a half weeks in Tampere, Finland, studying railroad engineering and Finnish language and culture.

\section{Opportunities}

The Association of American Railroads $(A A R)$ projects that the amount of freight shipped by rail will double over the next twenty years with major growth expected in the intermodal area. The AAR also identified that the rail industry has a significantly older workforce than the United States as a whole and that almost 40 percent of rail employees are eligible to retire within the next decade. (Railroads Say, 2004). A recent article in Trains noted that one of the greatest needs in the rail industry today and one of the greatest opportunities for employment is in engineering, particularly civil engineering, due to the squeeze in the supply of civil engineers and an expected demand for their expertise. This sudden need for a more engineers who are knowledgeable in rail topics and interested in rail careers becomes an unprecedented challenge for the industry's recruiting activities. Opportunities with rail consultants, transit consultants, and transit agencies also look promising as urban rail transit continues to grow with several commuter rail, streetcar, light rail transit, and other rail projects being planned. Graduate engineers will be needed in several area including civil, computer, electrical, environmental, and mechanical engineering.

The task of finding graduating engineers for the rail industry is not an easy one. At one time, railroad engineering was a common course in engineering programs and many students started exciting careers in the rail industry, but these courses have virtually disappeared and today few universities have a separate course and many do not even mention rail in their introduction to transportation engineering course. It has been many years since the railroads have been on campus recruiting and most students do not even 
think about potential opportunities with the rail industry. It has become a challenge for the rail industry to reinvigorate an interest in railroad careers. The American Railway Engineering and Maintenance-of-Way Association (AREMA), Committee 24 Education and Training, has become a leader in helping to do this. They are organizing seminars, developing course materials, and have coordinated the development of a new book, "Practical Guide to Railway Engineering”. The committee has also set several goals for the rail industry and one of the goals is the " 10 by 10 " initiative to re-establish railway engineering programs in 10 major U.S. universities by 2010 (Richards, 2005).

\section{The Michigan Tech Program}

Michigan Tech University saw a unique opportunity to combine an introductory course in railroad engineering with a study abroad component and it was first offered in summer 2004. It is an intensive five-week program in which students spent one week on the Michigan Tech campus, one-half week in Chicago, and three and a half weeks in Tampere, Finland, studying railroad engineering and Finnish language and culture. The closest rail service to campus is now over 50 miles away, so field trips to see rail operations and construction, and meet railroad engineers was seen as an important part of the program, so Chicago was selected. Chicago also provided the opportunity for lower air fares to Finland. Finland was chosen as the study abroad partner because of the Finnish heritage in the Houghton-Hancock area and an existing partnership with Tampere University of Technology. The primary instructor for the rail course was also born and raised in Tampere, Finland, and this made it easier to facilitate classroom space, living accommodations, and field visits.

The basic objectives of the program were to:

- introduce railroad engineering

- raise the level of interest in railroad engineering

- develop an awareness to different cultures and nationalities

The program was developed as a study abroad experience to provide the opportunities to incorporate field visits to rail facilities in the United States and Europe. It was also easier to overcome some administrative and personnel issues if it was offered as a summer program and at the time that the program was being planned the university was encouraging faculty to think about study abroad opportunities for our students. In addition to a technical course, students were required to take a language and culture course. Michigan Tech used the experience gained from working with Michigan State University in an instructor-escorted program in transportation engineering in Volgograd, Russia, that began several years ago. Students at Michigan State would take a technical course in the transportation engineering area and a course in Russian language and culture. The Michigan State program has been offered for several years and has continued to grow annually with additional course offerings.

The students in the Michigan Tech program take two courses - Introduction to Railroad Engineering ( 3 credits) and Finnish Language and Culture (3 credits). The railroad engineering course is a technical elective for our students and the Finnish language 
course can be used as a general education elective. Typically the railroad classes are in the morning and the Finnish classes are in the afternoon. Field tours and visits are incorporated throughout the program and are technical, cultural, or a combination of both. Tours may occur in the evenings or during the weekends. For example, one visit to a construction site in Finland starts at midnight, but because of Finland's latitude it is still daylight. The program runs from early-May to mid-June and the students have been juniors, seniors, and graduate students primarily in civil engineering.

\section{Introduction to Railroad Engineering}

The Railroad Engineering course has been planned to provide an introduction to the rail industry for students from different disciplines and among the topics include:

Introduction to railroads - history, terminology, railroads today, economics of rail transportation

Rail organizations

Railroad safety

Operations

Signals and communications

Railroad track location and design

Terminal, yard, and grade crossing design

Track construction and maintenance

Passenger rail operations

Introduction to urban rail transit

Technical field visits to see rail operations and construction were seen as a very important part of the course, so the schedule was planned so material was introduced and discussed prior to a field visit and the students would understand what they were seeing. Guest lecturers have been used for some topics and a range of instructional techniques are used because of the concentrated nature of the course. The first week is spent on campus covering the basics of railroads and providing a background for the technical tours in Chicago. The students travel from Houghton to Chicago and visit the National Railroad Museum in Green Bay, Wisconsin, enroute. During the first three years, university vans were used but this year a bus was chartered for the trip to Chicago. The field visits in Chicago include:

Belt Line of Chicago Hump Classification Yard

CSX Transportation Intermodal Yard

METRA (commuter rail) Traffic Control Center and Maintenance Shops

A Railroad Engineering Consultant (Patrick Engineering and TranSystems)

While in Chicago, the students are introduced to and ride the Chicago Transit Authority (CTA) and the Chicago O’Hare Airport People Mover. At the end of the second week, the students fly from Chicago to Finland to continue the program. In Finland, classes are held at the Tampere University of Technology in Tampere. The technical field trips in Finland include:

Finnish Railroad Administration

Helsinski Metro 
A rail construction site

EMMA (track measurement car)

The Pendolino (high speed train)

The students also have numerous opportunities to experience European passenger rail service and public transit.

\section{Finnish Language and Culture}

The goals of the Finnish language and culture course are to develop some conversational proficiency in Finnish and learn about the history and culture of Finland and its people. Finland is a country of 5.2 million people located between Sweden and Russia. The capital of Finland is Helsinki. Tampere is located about 100 miles northwest of Helsinki and has a population of a little over 200,000 . It is located at $62^{\circ} \mathrm{N}$ latitude and was originally the industrial city in Finland in textiles, wood, and manufacturing. Today Tampere is the home of Noika. Tampere University of Technology was founded in 1965 and today is the second largest university in Finland with over 11,000 students, primarily in engineering and technology programs.

Cultural field trips are a key part of the program. Prior to heading to Finland, students are introduced to several local Finnish customs and traditions in movies, music, foods, and conversation. In Finland, visits to traditional and historical sites in Helsinki and Tampere, attending a soccer (football) match and a Finnish baseball game, and enjoying a sauna at a typical summer cottage are a few examples that the students experience. The students live in apartments adjacent to the Tampere University of Technology campus so they become comfortable shopping in local grocery stores, shops, and restaurants. A weekend trip to Talinn, Estonia is also included and a free weekend is part of the Finnish experience. On the free weekend, students have organized trips to Sweden, northern Finland, and Europe, and following the program, many remain in Europe for an additional week of touring and sightseeing. In the first year, a local instructor from Finlandia University taught the Finnish language and culture course during the first week on campus and then a second instructor took over when the program reached Finland. In the second and subsequent years, the instructor from Finland traveled from Finland to teach the first week and then returned home and meets the group when they arrive in Finland. She also provides assistance with logistics and accompanies the students on both the technical and cultural tours in Finland.

\section{Program Cost for Students}

The cost of the program is kept low to encourage students to participate. There are probably three cost components for the students:

- A Program Fee (\$2200) which includes tuition (6 credits), fees, course materials, lodging in Chicago and Finland, some meals, all field trips and tours, and study abroad fees. To reduce the financial burden on students, the program was designed with six credits which entitled them to apply for financial assistance. 
This year through the generous contribution of the rail industry and alumni, over $\$ 11,000$ is available in scholarships to participants. Out-of-state students pay the same tuition as in-state students for study abroad programs at Michigan Tech

- Air fare (Chicago-Finland) - about $\$ 900$

- Other personal expenses (varies by student). The main expense is meals which are not covered in the program fee. In Finland, students have access to a kitchen in their apartments and university restaurants and dining facilities offer subsidized student prices.

The program has been budgeted to break-even. The costs of the instructors, course materials, field trips and tours, local travel, lodging in Chicago and Finland, some meals, and administrative and promotional activities are covered by the course fee.

\section{Experience}

Based on the student evaluations and feedback, the program has been a tremendous success. In the first year, 16 students participated in the program and they were primarily senior and graduate students in civil engineering. The program has since attracted students from other engineering disciplines on campus and other universities and in the first three years 40 students have taken the program. This year 23 students participated in the program and the mix of disciplines included mechanical, electrical, civil, surveying, materials engineering, and construction management students.

Six of the largest Class 1 railroads in the United States (CSX, BNSF, NS, Union Pacific, Canadian National, and Canadian Pacific) and Amtrak are now on campus recruiting. A summer internship program was developed in the second year and almost half of the students that participate in the program return to an internship position with a railroad after Finland. One student actually accepted a position with VR Track Limited (the Finnish national railroad). The internship program has grown as rail companies have started to recruit earlier and they have encouraged students to take the Michigan Tech program.

A scholarship fund has been established and after the first year of the program the students organized a Railroad Club on campus and it has become AREMA's first student chapter. The club has continued to grow with activities and tours throughout the year and it has raised the awareness of careers in the rail industry on campus and in the community through several outreach programs. The Railroad Club has also hosts an annual Railroad Night dinner that has attracted rail companies and they are now sponsoring the evening. This year over 100 students, university faculty and staff, and rail industry representatives attended the event. Several program participants have graduated and accepted positions in the rail industry. Newspaper and magazine articles have been written and the program has bought considerable national and international recognition to Michigan Tech. More information on the program, railroad activities at Michigan Tech, photographs and video clips of tours are on the web site www.cee.mtu.edu/railroad. 
From an instructor's viewpoint, it has been extremely rewarding to see so many students develop a passion for railroads and discover a foreign culture. For many students, it was their first trip outside of the United States. It will be one of those special experiences that will change their lives. Setting up and maintaining an international program in a field in which there was no previous experience on campus turned out to be a challenging but rewarding experience.

\section{Tips on Setting up a Study Abroad Program}

As one reflects on our experience with this study abroad program, there are exciting opportunities for other universities to set up similar programs in other subject areas. A few lessons or tips that we can share that may help others include:

Take the chance but ask yourself why you are doing it - there will be several obstacles, problems, and challenges and there is a lot of work to organize a study abroad program but don't be afraid as the reward in seeing the students discover a foreign culture and develop a passion for a course is tremendous.

Start early - allow yourself at least a year before the first class begins. This will give you time to make all the arrangements for the study abroad portion of the program, course development, the logistics, university approvals, and time to promote the program to potential students.

Establish a link with a study abroad location/university - look for a study location in which the students will have a good experience and will be safe. For our program Michigan Tech already had a partnership with Tampere University of Technology.

Find good people - the ideal situation is to select a location that you have good knowledge and contacts. We were extremely fortunate with our program as the Coordinator/Primary Instructor is originally from Tampere, worked in Chicago, speaks Finnish, is a graduate of Tampere University of Technology, and has numerous contacts in the rail industry in both the United States and Finland. He also has an unmatched enthusiasm for railroad engineering and his home country that is infectious.

Layout rules and expectations for students - the Michigan Tech Study Abroad Office conducts a compulsory orientation session for all study abroad students, but you must also establish rules or a code of conduct for the students in your program.

Promote the program and start recruiting students early - the ideal case would be at least a year ahead so that students can start to think how the courses will fit into their schedule and how they will pay for it. For an early summer program, like ours, you want to have a commitment on the number of students in January or February to make travel, tour, and housing arrangements. Develop a web site, prepare brochures and posters, hold introductory meetings, and be ready to answer lots of questions. 
Consider the currency exchange in your budget - if your program is expected to be financially self-sufficient, prepare for fluctuations and how to handle these changes.

Don't underestimate the importance of student finances - committing close to $\$ 4,000$ in just over a month is a difficult decision for most students and this may prevent many students from participating. The importance of keeping the fees low and supporting students through financial assistance and scholarships carries a heavy weight in the program success

Expect administrative questions - in many cases you will do things that are not covered in a current university policy, so expect to be asked to explain or document or develop a process to handle the situation. Don’t be discouraged.

Don't panic - no matter how planning and advance work that you do, the unexpected will happen.

\section{The Future}

The rail industry is facing a major challenge of attracting students to rail careers and there are several approaches that universities can take to help. The Michigan Tech five-week intensive program with a study abroad feature has been an exciting one that has generated lots of interest and has placed Michigan Tech on the list of a few universities where railroads now want to recruit.

\section{References}

Railroads Say “You're Hired!” - Railroads Expect to Hire More than 80,000 New Workers Over the Next Six Years (2004), Press Release, Association of American Railroads, April 28, 2004.

Richards, Dallas (2005), Railway Engineering in the $21^{\text {st }}$ Century, in HDR Inc. Rail Line newsletter, May 2005.

Hansen, P.A., Those Who Can Teach: Whether the Collar is Blue or White, the Person Wearing it Need to be Well Trained, Trains, 2005, Vol. 65, No. 5, pp.48-53

Lautala, P.T. and Sproule, W.J., Educating New Railroad Engineers - an International Summer Program at Michigan Tech University, Proceedings of AREMA Annual Meeting, American Railway Engineering and Maintenance-of-Way Association, 2004.

Lautala, P., International Summer Program in Railroad Engineering, Proceedings of ASEE/IEEE Frontiers in Education Conference, San Diego, CA, October 2006.

Lautala, P., Development of University-Industry Partnerships in Railroad Engineering Education, unpublished Ph.D. dissertation, Michigan Tech University, Houghton, MI, August 2007. 
PASI T. LAUTALA is an Instructor and Director of the Railroad Engineering Program, Michigan Tech University, Houghton, MI. Pasi has several years of experience in the rail industry, transportation consulting in both Finland and the United States.

WILLIAM J. (BILL) SPROULE is a Professor, Department of Civil and Environmental Engineering, Michigan Tech University, Houghton, MI. Bill has over 30 years experience in government service, consulting, and university teaching and research in Canada and the United States. He teaches and conducts research in several areas including traffic engineering and safety, transportation planning, airport design, and hockey history. 